This item was submitted to Loughborough's Research Repository by the author.

Items in Figshare are protected by copyright, with all rights reserved, unless otherwise indicated.

\title{
Analysing sport policy and politics: the promises and challenges of synthesising methodological approaches
}

\section{PLEASE CITE THE PUBLISHED VERSION}

https://doi.org/10.1080/19406940.2018.1450773

\section{PUBLISHER}

(C) Taylor \& Francis (Routledge)

\section{VERSION}

AM (Accepted Manuscript)

\section{PUBLISHER STATEMENT}

This is an Accepted Manuscript of an article published by Taylor \& Francis in International Journal of Sport Policy and Politics on 10 May 2018, available online:

http://www.tandfonline.com/10.1080/19406940.2018.1450773.

\section{LICENCE}

CC BY-NC-ND 4.0

\section{REPOSITORY RECORD}

Whigham, Stuart, and Alan Bairner. 2018. "Analysing Sport Policy and Politics: The Promises and Challenges of Synthesising Methodological Approaches". Loughborough University. https://hdl.handle.net/2134/32185. 


\title{
Analysing sport policy and politics: the promises and challenges of synthesising methodological approaches
}

\author{
Stuart Whigham (Oxford Brookes University, UK) \\ Alan Bairner (Loughborough University, UK)
}

\begin{abstract}
This article reflects upon the potential analytical utility of synthesising contrasting methodological frameworks when conducting research on sport policy and politics, with specific reference to methods derived from the fields of critical discourse analysis, political discourse analysis and narrative analysis. In particular, this article critically reflects upon the political discourse analysis framework proposed by Isabela Fairclough and Norman Fairclough (2012), and the narrative analysis framework proposed by Margaret Somers (1994), drawing upon the findings of research which synthesised these distinct yet complementary analytical frameworks. With its central emphasis on the content and production of political discourse relating to the 2014 Glasgow Commonwealth Games and the Scottish independence referendum, the methodological processes used in this thesis focused upon the identification of recurrent discursive forms from primary and secondary data sources including interviews with political actors, speech transcripts, manifestos, policy documents and press releases. Given the methodological synthesis evident in this approach, this article firstly provides a discussion of the paradigmatic assumptions of this analytical synthesis. Discussion then focuses on the provision of a more detailed outline of the Fairclough and Fairclough (2012) and Somers (1994) frameworks, and an explanation of the synthesis of the specific analytical frameworks adopted and the specific empirical methods employed. Finally, this article provides a reflexive critique of the relative merits of the chosen methodology, with specific consideration given to the promises and challenges of synthesising analytical frameworks in a similar fashion in future research within the field of sport policy and politics.
\end{abstract}

Keywords: critical discourse analysis, political discourse analysis, narrative analysis, sport politics, Commonwealth Games, Scottish independence 


\section{Introduction}

The goal of this article is to reflect upon the potential analytical utility of synthesising contrasting methodological frameworks when conducting research on sport policy and politics, with specific reference to methods derived from the fields of critical discourse analysis, political discourse analysis and narrative analysis. In particular, the article considers the political discourse analysis framework proposed by Isabela Fairclough and Norman Fairclough (2012), and the narrative analysis framework proposed by Margaret Somers (1994) and seeks to demonstrate the value of synthesising these distinct, yet complementary, analytical frameworks.

This approach has been used to identify recurrent discursive forms from primary and secondary data sources relating to the 2014 Commonwealth Games and the Scottish independence referendum. Sources included interviews with political actors, speech transcripts, manifestos, policy documents and press releases. These sources were critically scrutinised using the aforementioned analytical approach in order to explore the extent to which the staging of the Games in Scotland was exploited politically in relation to debates about the nation's constitutional future. Given the importance of the referendum and its proximity to the Games, it is unsurprising that the event became intertwined with political positioning from parties on both sides of the constitutional debate. Indeed, it has been argued that the relative success of these campaigns can be partly attributed to their ability to construct coherent narratives of their visions for Scotland after the referendum through effective political communication (Arnott and Ozga 2010, Charteris-Black 2014, McNair 2011). 
First, the article discusses the paradigmatic assumptions of our analytical synthesis by exploring the fundamental principles of critical discourse analysis and narrative analysis. Attention then turns to providing a more detailed outline of the frameworks of Fairclough and Fairclough (2012) and Somers (1994), and an explanation of the synthesis adopted as well as the empirical methods employed to demonstrate the salience of this synthesis. Finally, the article offers a reflexive critique of the relative merits of the chosen methodology, with specific consideration being given to the promises and challenges of synthesising analytical frameworks in a similar fashion in future research within the field of sport policy and politics.

\section{Principles of Critical Discourse Analysis}

The overarching analytical approach used to drive the methodological synthesis adopted in this article is critical discourse analysis (CDA), an approach which incorporates a varied range of conceptual and analytical approaches. It is important to note that, despite its diversity, CDA represents only one analytical approach in the academic study of discourse. For example, Titscher et al.’s (2000) guide to textual and discourse analysis identifies ten methods of analysis within the field of discourse studies in addition to CDA. Whilst all of these methods have a common interest in scrutinising texts as a means of understanding social realities, they are differentiated by their relative emphases on the content, structure and contexts of a given text. For example, conversation analysis, narrative semiotics and functional pragmatics place greater emphasis on the structural features of a given text, whereas approaches such as CDA give primacy to scrutinising the impact on the character of the discourse of the broader social and political context (Fairclough 2015, Titscher et al. 2000). It is unsurprising, therefore, that analytical approaches such as CDA have attracted attention from academics interested in political discourse and policy within the domain of 
sport, given its emphasis on exploring the ideological positions which underpin prevalent discourses within the sporting world (Liao and Markula 2009, Piggin 2014).

The work of Fairclough and Wodak (1997) remains the most influential contribution to the original theoretical foundations of the CDA approach, although their differing approaches to CDA led to a significant cleavage in their subsequent methodological direction (Blommaert 2005, Titscher et al. 2000). Despite this cleavage, however, Fairclough and Wodak (1997, p. 258) retained a shared appreciation of the importance of conceptualising discourse as a form of 'social practice', arguing that “discourse as social practice implies a dialectical relationship between a particular discursive event and the situation(s), institution(s) and social structure(s) which frame it”. Another leading scholar in the field of CDA, Van Dijk (1996, p. 84) similarly highlights the importance of scrutinising the dialectic between discourse and its context:

...one of the crucial tasks of Critical Discourse Analysis (CDA) is to account for the relationships between discourse and social power. More specifically, such an analysis should describe and explain how power abuse is enacted, reproduced or legitimised by the text and talk of dominant groups or institutions.

CDA approaches have also been argued to share a number of theoretical influences which unite the various traditions situated within the field. Titscher et al.'s (2000) and Blommaert's (2005) reviews of the field particularly identify the influence of neo-Marxist theoretical concepts on CDA, given the latter's explicit goal of adopting a critical stance in relation to contemporary capitalist societies and discourse emanating from such societies. Examples of the neo-Marxist influences on the theoretical underpinnings of CDA have been argued to include Althusser’s conceptualisation of ‘ideological state apparatuses’, Bakhtin’s ‘genre 
theory’, and Gramsci’s concept of 'hegemony’ (Blommaert 2005, Fairclough 2015, Titscher et al. 2000). Furthermore, Fairclough's version of CDA has also been influenced by the work of Michael Halliday on systemic functional linguistics (SFL) which places emphasises the need to consider the functions or goals of language use as means to an end, rather than the structure and content of language as an end in itself (Fairclough 2003, 2015, Titscher et al. 2000). Given that these theoretical assumptions place emphasis on the socially-constructed nature of discursive acts, as well as the impact of neo-Marxist thought and its concomitant scrutiny of ideological influences on discourse, it is apparent that the ontology and epistemology of CDA are strongly aligned with the prevalent interpretivist and subjectivist positions embraced within the broader domain of qualitative research approaches (Denzin and Lincoln 2003, Guba and Lincoln 2005, Jones 2015, Lincoln 2010, Silk, Andrews and Mason 2005, Sparkes and Smith 2014).

Accordingly, Fairclough argues that the distinction between 'textually-oriented discourse analysis' and other forms which do not scrutinise texts should be transcended, recommending an oscillation between the content of specific texts and the 'orders of discourse' within which the texts are situated (Fairclough, 2015). Fairclough (1992) also highlighted the importance of appreciating the 'intertextuality' evident in a given form of discourse. He therefore argued that CDA is underpinned by an appreciation of the importance of an 'intertextual analysis' which demonstrates "how texts selectively draw upon orders of discourse - the particular configurations of conventionalized practices (genres, discourse, narratives, etc.) which are available to text producers and interpreters in particular social circumstances” (ibid: p. 194; original emphasis). This position emphasises the common tendency for social actors to draw upon pre-existing narratives and textual representations when creating their own discursive forms, thereby signposting the potential synergy between CDA and narrative analysis, with 
both the content and structure of texts being influenced by the 'orders of discourse' which are prevalent in a given social context. Fairclough (2015) elaborates on this point by drawing upon the work of Foucault, arguing that "conventions and orders of discourse, moreover, embody particular ideologies” (ibid: p. 60).

Fairclough's arguments concerning the importance of scrutinising the ideological context of discourse through the use of a CDA approach have been applied to a number of issues within the field of sport. For example, applications of CDA have been seen in past analyses of such issues as sports media discourse and representations (Kelly 2010, Liao and Markula 2009, Wolter 2015), physical education and youth sport (Mean and Kassing 2008, Rich and Giles 2014), sports advertising and marketing (Lee 2015), and sport policy discourse (Jedlicka 2014, Piggin, Jackson and Lewis 2009, Piggin, 2014). The wide variety of topics and methodological approaches embraced within this corpus of CDA-oriented research in sport suggests the continuing relevance of exploring the predominant discursive patterns which emanate from the sporting world. Furthermore, the field of sport policy and politics remains a particularly ripe arena for further applications of the principles of CDA; attention will thus turn to one particular CDA-oriented framework which has potential analytical utility in this field, namely Fairclough and Fairclough’s (2012) political discourse analysis framework.

\section{Fairclough and Fairclough's (2012) Political Discourse Analysis Framework}

Given CDA's prioritisation of the ideological features of discourse within academic research, it is unsurprising that one of the main domains for the application of CDA has been that of politics. Nonetheless, there is a degree of variation in the analytical methods proposed and adopted in studies of political discourse. The specific methodological synthesis adopted in 
this study selected the political discourse analysis (PDA) framework developed by Fairclough and Fairclough (2012) which allows for emphasis on the unique nature of discourse in the political realm. Furthermore, the Fairclough and Fairclough (2012) model develops Norman Fairclough's earlier work in the broader field of CDA, thus retaining the core analytical, onotological and epistemological underpinnings of CDA outlined in the previous section whilst simultaneously producing an analytical framework which solely focuses on political discourse.

The work of Fairclough and Fairclough (2012) is characterised by its integration of argumentation theory with the analytical framework, with the authors arguing that their analytical approach conceptualises “political discourse as primarily a form of argumentation, and as involving more specifically practical argumentation, argumentation for or against particular ways of acting, argumentation that can ground decision” (Fairclough and Fairclough, 2012, p. 1; original emphasis). This prioritisation of argumentation theory demands a particular analytical mind-set on the part of its adherents, with a specific goal being the identification and critique of core 'practical arguments' proposed by political actors in relation to a specific set of circumstances. The explication of these practical arguments represents the fundamental purpose of any political speech, publication or other discursive form:

In our view, focusing on the structure of argumentation in a political speech is relevant... as the purpose of the speech, what it is designed to achieve, may be to convince an audience that a certain course of action is right or a certain point of view is true, and this is the intended perlocutionary effect that is intrinsically associated with the speech act of argumentation (Fairclough and Fairclough, 2012, p. 18; original emphasis). 
This integration of argumentation theory within Fairclough and Fairclough's analytical framework therefore distinguishes it from the contrasting CDA-oriented frameworks outlined in the previous section. This distinctive approach thus provides scholars in the field of sport policy and politics with a bespoke analytical approach for scrutinising the specific arguments embedded within sport-related political discourse. Furthermore, this approach provides a clear framework linking broader ideological values to the exploration of practical arguments made within a specific discursive act.

Furthermore, and of central importance to the methodological synthesis utilised in this article, the analytical framework identifies a number of contrasting discursive features within political arguments, including 'imaginaries' and 'narratives'. Explicit identification of the importance to political discourse of 'narratives' signposts potential synergy with the principles of narrative analysis themselves. Fairclough and Fairclough (2012) argue that 'narratives' and 'imaginaries' act as ways of realising mental conceptions in a discursive form. These contrasting discursive representations differ in terms of their argumentative properties, with Fairclough and Fairclough claiming that these elements should be incorporated in different fashions in an analysis of political discourse:

...narratives... are incorporated within what we will call the 'circumstantial premises’ of practical arguments (premises which represent the context of action); 'imaginaries' for possible and desirable states of affairs are incorporated in our account within the 'goal premises' (Fairclough and Fairclough, 2012, p. 4).

Recognition of the important role of 'narratives' provides the basis for a thorough contextualisation of a particular political argument or future 'imaginary'; however, these 'narratives' are argued to be subservient to 'imaginaries' in terms of their importance: 
Although 'imposing' or winning acceptance of particular representations (descriptions, narratives, explanations) and thereby shaping perceptions are concerns in politics, we would argue that they subserve a greater concern of political agents and agencies to make their proposed lines of action, their strategies and policies, prevail over others. (Fairclough and Fairclough, 2012, p.

4)

Fairclough and Fairclough (2012, p. 104) attribute this subservience to the fact that imaginaries "as future visions, capable of guiding action are assigned to the goal premises [of a practical argument], while semiotic representations of the actual world are assigned to the circumstantial premises” (original emphasis). This means that the category of representations, such as 'narratives', simply describes the past and present state of affairs and is thus non-argumentative in character; only 'imaginaries' have the power to motivate future political action (Fairclough 2015, Fairclough and Fairclough 2012). Whilst the 'imaginary' is conceptualised as the central catalyst in political discourse and argumentation, the subservient position in Fairclough and Fairclough's framework of non-argumentative representations, including narratives, demands further discussion. Although narratives are explicitly held to be non-argumentative, they are still conceptualised as playing a role in the construction of effective practical argumentation due to their function in representing the 'circumstantial premises' of an argument. However, the authors caution that non-argumentative genres such as narratives should not be analysed in isolation. They contend that "[a]nalysis of nonargumentative genres (narratives, explanation) should also be view in relation to the arguments in which they are usually imbedded” (ibid, p. 1). The authors are therefore critical of those studies which scrutinise the framing and narration of political discourse as an end in itself. 
In terms of visualising the constituent structure of their analytical framework, Fairclough and Fairclough (2012) use a number of diagrammatic forms to demonstrate various features of effective political argumentation. The first of these diagrams represents the foundations of their proposal for analysing the structure of practical arguments (see Figure 1):

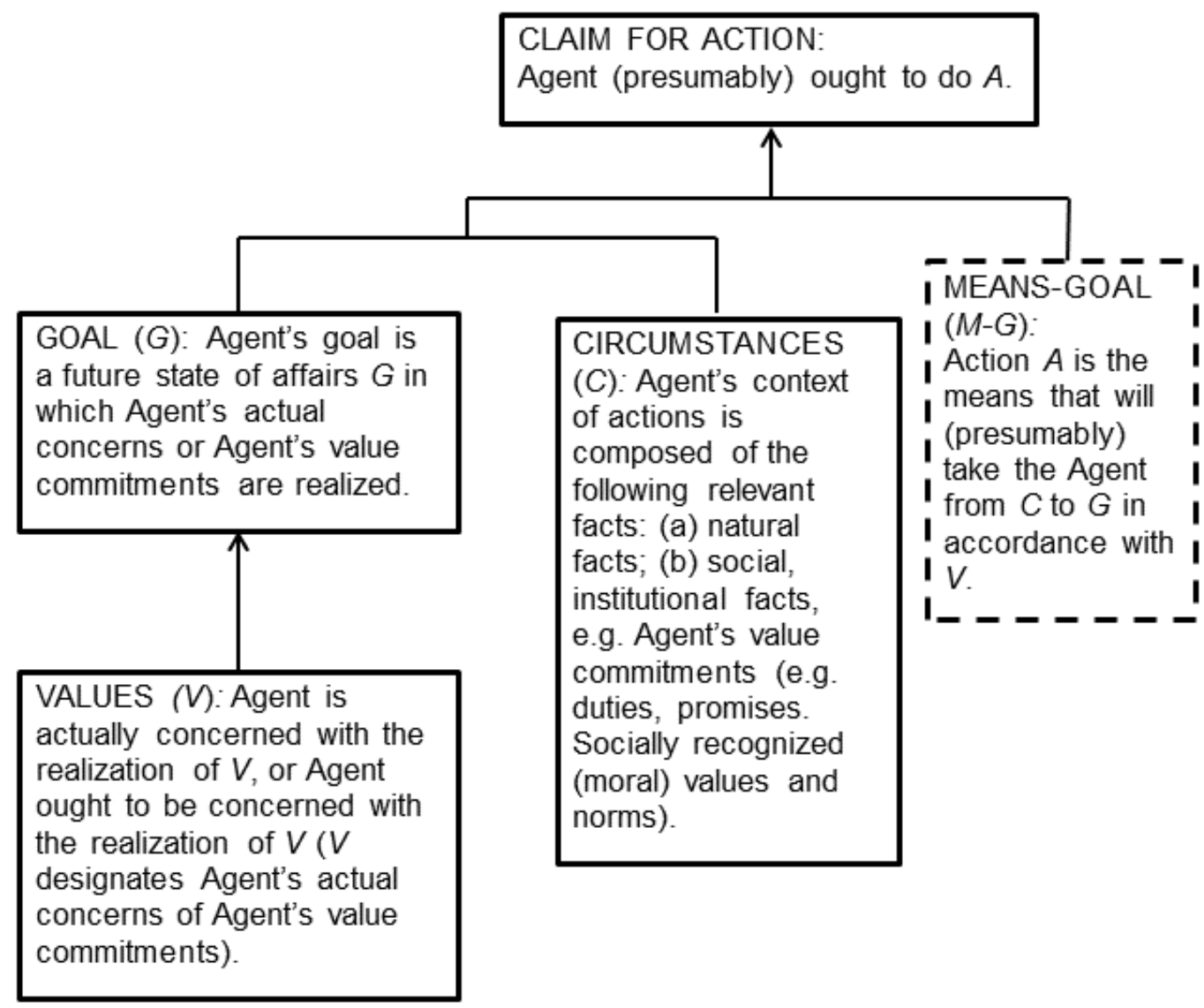

Figure 1 - Diagrammatic representation of the structure of practical reasoning (Fairclough and Fairclough 2012, p. 48)

Elaborating on the conceptualisation of political discourse outlined in the framework illustrated in Figure 1, it is clear that emphasis is placed on the central importance of an actor's political and ideological 'values' in shaping their discourse and their political 'goals'. 
Complementary to these political 'values', the contextual justification for a specific course of action is provided via a discursive representation of past and present 'circumstances', thereby highlighting that the current state of affairs requires a specific political action or 'goal'. These political 'goals' are in turn representations of a future political 'imaginary', and are therefore represented in positive terms as worthwhile political pursuits. In order to achieve her goals, a political actor must motivate others to act in a manner which will achieve this future 'imaginary'; the 'means-goal' component of political discourse is thus focused upon the specific actions required to achieve a given 'goal', with a 'claim for action' acting as the ultimate recommendation for practical action by political actors or the electorate.

According to Fairclough and Fairclough (2012), this diagrammatic model acts a means of simplifying the complexities of a particular political argument. Further elaborations on the basic analytical framework are made through Fairclough and Fairclough's (2012) application of it to the 'Third Way' discourse of 'New Labour' and discourse relating to the 2008 global financial crisis. In this way, they seek to demonstrate the potential flexibility and fluidity of the framework ${ }^{1}$ which allow scope to tailor the analytical focus to the specific content of the discursive form under scrutiny at a given time and lets the analyst align the framework with the chosen data sample. However, this flexibility arguably comes at the price of analytical clarity, given the ambiguity which emerges due to these required elaborations.

1 For example, 'negative consequences' of a particular course of 'action', whereby a political actor argues against an action by highlighting its negative impact in terms of achieving his/her 'goal', and representations of these negative consequences are used therefore to underpin a 'counter-claim' which explicitly denounces a suggested course of action the additional analytical categories of 'alternative options' and 'addressing alternative options' are argued to be evident in a speech by Tony Blair outlining his vision for the 'Third Way', three more categories are identified in an analysis of the 2008 Pre-Budget Report ('anticipated objection', 'dealing with objection', and 'argument for authority'), and, finally, four more elaborate categories ('counter-argument and alternative proposal'; 'dealing with counter-argument and alternative: negative consequences of both'; 'emerging positive consequences of action already taken'; 'dealing with anticipated negative consequences of proposed action') are added in the analysis of the 2010 June Budget speech (Fairclough and Fairclough, 2012). 
Bearing such caveats in mind, it is important to stress that the framework's core analytical categories of 'values', 'goals', 'circumstances' and 'action' remain evident in all of these applications, thus ensuring that the fundamental principles of the framework remain consistent. However, the treatment of 'narrative' representations as non-argumentative forms of discourse remains problematic; attention will therefore now turn to considering the possibility of complementing this aspect of Fairclough and Fairclough's framework by discussing the theoretical principles associated with narrative analysis.

\section{Principles of Narrative Analysis}

Narrative analysis (NA) acts as the second central theoretical component of the analytical synthesis deployed in the present methodological approach. NA has become increasingly popular in the social sciences following the widely-discussed 'narrative in the 1980s (Czarniaska 2004, Smith and Sparkes 2008). The fundamental epistemological belief which underpins NA lies in its emphasis on the importance of examining the content, character and structure of stories told by individuals and collectives in a given society as a means of understanding the lived experiences of that society's members (Bruner 1990, Ricoeur 1984, Somers 1994, Smith and Sparkes 2008).

Smith and Sparkes’ (2008) review of the main traditions in narrative inquiry identifies a diverse range of social theorists who have engaged with NA in various academic fields. They identify five contrasting perspectives which have prevailed, aligning a number of influential social theorists to each perspective, including the 'psychosocial' (e.g. Crossley 2000, McAdams 1993), ‘inter-subjective’ (e.g. Bruner 1990, Ezzy 1998, Ricoeur 1984), ‘storied resource’ (e.g. Gubrium and Holstein 1998, Riessman 1993, Somers 1994), ‘dialogic’ (e.g. 
Bakhtin 1981, Frank 2005, Hermans 2001) and 'performative’ (e.g. Gergen 1999, 2001) to NA. Although this diversity leads to a plethora of contrasting methodological and ontological positions, the different perspectives retain a shared belief that narratives act as crucial phenomena in the shaping of our social world and our understanding of individual social experiences. Furthermore, NA aligns with the epistemological and ontological assumptions of interpretivist, qualitative research, echoing many of the foundational assumption of CDA and the Fairclough and Fairclough (2012) model of political discourse analysis.

Daiute and Lightfoot's (2004) introduction to their edited collection on NA research reflects upon the main benefits of this approach, highlighting: its preference for a holistic examination of social phenomena, the opportunity it provides to examine the contexts of wider social histories which influence an individual's identity, the insight that the approach offers in terms of highlighting factors which shape the relationship between the self at the agency level and society at the structural level, and, finally, the acceptance (and encouragement) of subjectivity and value judgements on the part of researchers as a primary aim in their analyses. Sparkes and Smith (2014) draw similar conclusions regarding the potential benefits of NA for the academic study of sport, exercise and health, placing particular emphasis on its prioritisation of the experiences of individuals and groups as social actors.

However, despite their explication of the various benefits of NA in sport, exercise and health research, Sparkes and Smith offer relatively few examples of narrative analyses conducted at a macro-analytical level which they term a 'structural analysis of narrative types'. Therefore, the majority of the studies which they cite derive from the fields of psychology and social 
psychology in sport, rather than sociological or, as in this case, political analysis related to the domain of sport. Indeed, it can also be argued that a similar lack of macro-level and mesolevel critical analysis is evident with regards to past studies of sport policy discourse due to the 'taken-for-granted' assumptions which often emerge within sport policy (Piggin, Jackson and Lewis 2009). To this end, the synthesis of NA with discourse analysis frameworks such as that of Fairclough and Fairclough (2012) which have greater emphasis on macro-level political discourse thus facilitates an opportunity to examine emergent narrative tropes at this higher level of policy analysis.

\section{Somers's (1994) Framework of Narrative Dimensions}

In terms of specific theoretical frameworks within the field of NA, Margaret Somers’s (1994) framework of narrative dimensions has been particularly influential. Somers identifies four ‘dimensions’ of narrative which operate at different levels of sociological abstraction and analysis: ‘metanarratives’, 'public narratives’, ‘ontological narratives’ and 'conceptual narratives'. At the macro-sociological level, the concept of 'metanarratives' is used to denote narratives "in which we are embedded as contemporary actors in history and as social scientists” (ibid, p. 619), such as 'Progress', ‘Enlightenment' and ‘Capitalism versus Communism'. At a meso-sociological level of analysis, Somers uses the term 'public narratives' to identify those forms which emanate from societal formations, including those presented by formal social institutions such as governments, political parties, religious institutions, educational establishments and the media, as well as the individual's social network of family and friends. As well as identifying the role of political parties in the creation of 'public narratives', Somers also identifies the prevalence of nation-centric 
narratives within this element of her framework. The potential utility of this model for the study of political narratives is therefore apparent.

While the concepts of 'metanarratives' and 'public narratives' are used to denote narratives which operate at the structural level of sociological analysis, Somers contends that the influence of these external narratives on an individual's sense of self can be analysed by considering micro-sociological, agency-level ‘ontological narratives’ constructed by individual social actors when they synthesise their fragmentary life experiences, belief patterns and emotions into a coherent narrative of the self. It is argued, therefore, that this dialectical relationship between narratives at the macro-sociological (i.e. 'metanarratives'), meso-sociological (i.e. 'public narratives') and micro-sociological (i.e. 'ontological narratives') levels can be used to theoretically negotiate the duality whereby social agents are influenced by external social forces at a structural level while also constituting these social forces through the collective action.

The potential utility of NA for the study of political phenomena such as nationalism is underlined in the work of Hearn (2002) who draws upon Somers’s (1994) model in his own analysis of Scottish nationalism, echoing the approach used in the current methodological synthesis which will now be explained in greater detail.

\section{Methodological Synthesis - The Complementarity of Narrative Analysis and Political Discourse Analysis}

Given the similarities with between the ontological and epistemological positions of NA and CDA which are synthesised within the current methodological approach, alignment with an 
interpretivist stance which places emphasis on the exploration of the reasons for the patterns which emerge from empirical data, as opposed to a reductionist description of these patterns in isolation, is emphasised (Denzin and Lincoln 2005, Guba and Lincoln 2005, Silk, Andrews and Mason 2005). This alignment with the interpretive paradigm and our adoption of qualitative research methods in this study are influenced by a pragmatic stance, in light of the benefits of such approaches for developing rich data and a nuanced understanding of the complex discourse under scrutiny. Our strong alignment with the epistemological assumptions of the interpretivist paradigm precludes the adoption of a positivist or postpositivist ontological position, given the latter's emphasis on objectivity, a goal which is highly questionable in any research on political discourse due to the undoubted subjectivity of all researchers (Berling and Beuger 2013). This alignment with the axiological position of CDA which permits and encourages the incursion of personal political values into the research process (Fairclough 2003, 2015) thus endeavours to refute any such claims of objectivity.

Instead, interpretivist qualitative research embraces the subjectivity so feared in the positivist paradigm because, by adopting a reflexive approach to research, it is possible to effectively identify the subjective biases which may shape one’s own interpretation of a specific subject, given the constructed nature of knowledge (Bourdieu 1990, Sparkes 2002, Wacquant 1992). Furthermore, this stance promotes a healthy element of self-doubt in relation to the robustness and validity of one's own research findings which ultimately gives scope for healthy academic debate and scholarship. Rejection of traditional positivist 'scientific' criteria thus allows interpretivist qualitative research to free itself from potential methodological and paradigmatic constraints, facilitating the development of innovative 
methodologies which effectively align with the research question in hand (Sparkes and Smith, 2014).

Turning to the specifics of the innovative methodological synthesis employed in this analysis, one of the central aims of the research project that forms the basis of this paper was to identify the 'metanarratives' and 'public narratives’ which are invoked by various political stakeholders in Scotland, with the eventual goal of contrasting the different narrative tropes associated with each party. In particular, narratives which were deployed as representations of Scotland's past, present and future in political discourse relating to Scotland's constitutional status were scrutinised together with 'public narratives' about the Glasgow Commonwealth Games. The importance of developing coherent narratives in order to sustain effective political campaigns has been acknowledged in recent studies of political communication (Arnott and Ozga 2010, Charteris-Black 2014, McNair 2011). The synthesis of Somers’s (1994) framework with that of Fairclough and Fairclough’s (2012) was used, therefore, to redress a potential imbalance concerning the supposed 'non-argumentative' nature of narratives on the current 'circumstantial premises' of Scotland's political status.

In order to scrutinise emergent patterns in political discourse relating to the Games and the independence referendum, Fairclough and Fairclough’s (2012) framework has been selected as a means of identifying the 'goals' and 'values' of contrasting Scottish political parties.. Although the two frameworks derive from contrasting methodological schools, their synthesis centres on the synergy between Somers's concept of the 'public narrative' and Fairclough and Fairclough’s notions of ‘circumstantial premises', 'goal premises’ and ‘imaginaries’. As outlined earlier, in the eyes of Fairclough and Fairclough (2012), these political narratives constitute the 'circumstantial premises' of a specific example of political 
discourse. The 'public narratives' of a given political party are therefore harnessed to create a representation of a particular set of past or present circumstances which is then used to contextualise a particular argument for future political action, taking the form of an ‘imaginary' which acts as an idealised representation of future circumstances or 'goal premises'.

Applying this logic to the case in hand, the character of 'public narratives' relating to the past, present and future of Scotland's constitutional status in the discourse of selected Scottish political parties was examined. These past and present representations constitute the ‘circumstantial premises' of Fairclough and Fairclough’s framework, while the future tense representations constitute the 'imaginary' and 'goal premises' elements of the framework. Given that Fairclough and Fairclough argue that 'imaginaries' act as catalysts for argumentation in political discourse, an analysis of the contrasting representations evident in discourse from across the Scottish political spectrum provided an opportunity to examine the values and ideologies of each respective party. Furthermore, it was also possible to ideologically contextualise discourse from the selected parties which related to the 2014 Commonwealth Games specifically. This two-tiered analysis thus facilitated a nuanced understanding of the political values which were evident in each party's stance on the political ramifications of the Games, as these issues could be framed within each party's wider political vision, or 'imaginary’, concerning Scotland's constitutional future (Arnott and Ozga 2010).

In practice, this meant a two-stage data collection process, the first of which involved scrutiny of political discourse which directly discussed the 2014 Glasgow Commonwealth Games and the Scottish independence referendum, Texts included official press releases, 
webpages, speech transcripts, parliamentary contributions, political manifestos and policy documents, totalling 662 secondary data sources. Each source was uploaded into the NVivo qualitative data analysis software, with an open coding system used to identify emergent themes, followed by an axial coding process which sought to categorise these lower-level codes into higher-level discursive forms using the framework proposed by Fairclough and Fairclough (2012). The data analysis process drew upon the principles of both CDA and NA, with an emphasis on identifying narrative forms associated with each data item and the language being used by each party to create particular narrative tropes.

The emergent themes and narrative tropes from the political discourse sample were later reflected upon critically through the second-stage of the data collection process which comprised analysis of interviews and surveys with Members of the Scottish Parliament (MSPs) from the parties included in the sample. Nine MSPs participated, two each from the SNP, Scottish Labour, the Scottish Conservatives and the Scottish Greens, and one from the Scottish Liberal Democrats. The interview transcripts were uploaded and again analysed using the NVivo software package. Particular attention was paid to exploring the strategic thinking and ideological values which underpinned the production of political discourse and narratives relating to the Games and the referendum. Furthermore, the interviews were also used to further reflect upon the nature of the 'values', 'goals' and 'means-goal' positions of each party in line with Fairclough and Fairclough’s (2012) analytical framework, with the interview data providing an opportunity to discuss in greater depth the nuances of each party's approach to the Games and to sport as a general policy area.

\section{Methodological Synthesis in Practice - Contrasting Narratives and Discourses of}

\section{Glasgow 2014}


In order to illustrate the practical benefits of the methodological synthesis outlined above, the following section provides examples of the results of the analytical strategies adopted in this project. Specifically, data from the analysis of the discourse of the Scottish Greens and the Scottish Conservatives is presented below, thus facilitating a comparison of two parties representing contrasting positions on the ideological spectrum in Scottish politics, with the Scottish Greens constituting the most left-leaning party in the Scottish and the centre-right Scottish Conservatives being positioned farthest to the ideological right in the Parliament (Anderson 2016; Leith and Soule 2011). Focusing on an ideological comparison of this nature in the following discussion specifically illustrates the impact of these contrasting positions on each party’s narratives and discourse regarding the Glasgow 2014 Commonwealth Games.

Although the Scottish Greens and the Scottish Conservatives were minority parties within the Scottish Parliament at the time of the 2014 Games, with 2 MSPs and 15 MSPs respectively, this means that they have been relatively neglected in past academic analyses of the political ramifications of the 2014 Games in comparison to the governing SNP and the main opposition party, Scottish Labour (see Harris and Skillen 2016; Jarvie 2017; Mole 2014; Ochman 2013; Whigham 2017). An exploration of the discourse of the Scottish Greens and the Scottish Conservatives provides an opportunity to explore contrasting ideological positions on the Games, distinct from the centre-left orthodoxy argued to be prevalent within the discourse of the SNP and Scottish Labour (Leith and Soule 2011; Anderson 2016).

The Scottish Green Party - A ‘Green Yes’ and Green Games? 
Based on analysis of the Greens’ recent election manifestos from the pre-Games period and the party's policy document on the topic of Scottish independence entitled 'A Green Yes', Figure 2 provides a diagrammatic representation of the Greens’ political discourse regarding Scotland's constitutional status using the Fairclough and Fairclough (2012) framework,

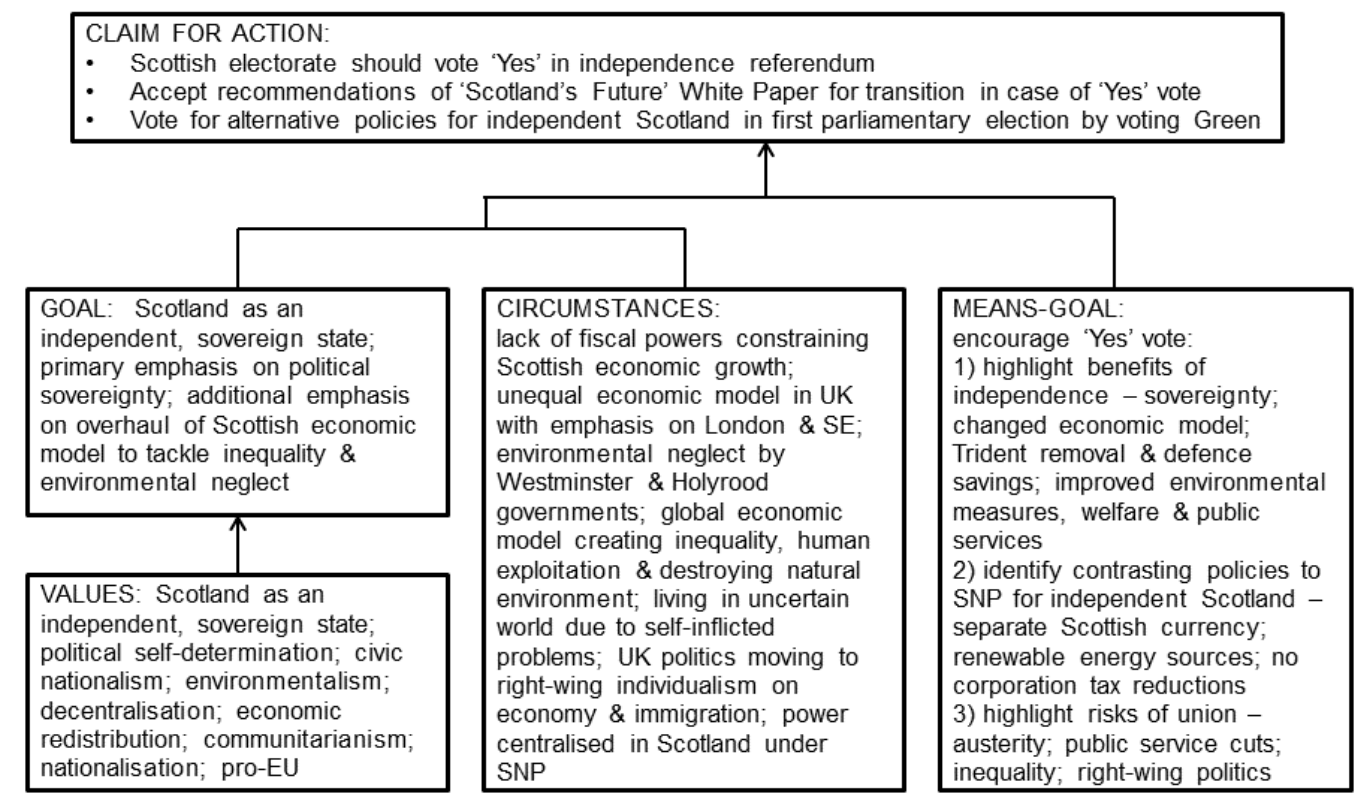

Figure 2 - Diagrammatic representation of Scottish Green Party political discourse regarding $\underline{\text { Scotland's constitutional status }}$

Analysis of the Greens' ‘public narratives’ of the present 'circumstances’ of Scottish society demonstrates the contrasting ideological stances evident within the pro-independence campaign. For example, their stance on Scottish politics echoes the arguments of the SNP in relation to the Scottish 'democratic deficit'. However, for the Greens this deficit is specifically argued to manifest itself in an inability to tackle inequality and poverty due to the lack of fiscal powers:

Devolution has given Scotland a Parliament which can fire-fight the worst manifestations of poverty, but is incapable of the action needed to truly close the 
gap between rich and poor; or even between the rich and the rest. (A Green Yes, 2014, p. 3)

The Greens highlight the growth of inequality in the UK as a contributory factor to these circumstances for Scotland; however, their position also suggests that a similar economic model is evident in Scotland under the SNP. This narrative therefore avoids solely pinning the blame for inequality on the Conservative UK Government, emphasising instead the adherence to a neo-liberal economic model as the primary cause of damage to Scotland's economy, society and environment.

The Greens' discourse on the issue of the environment also acts as an interesting barometer for the party's particular political stance. For example, the party differentiates itself from others by highlighting the responsibilities of other political parties for environmental neglect, given their adherence to the prevalent neo-liberal global economic model:

Governments of all colours in London and Edinburgh have neglected our environment, let inequality widen, and narrowed our politics. Only Greens are offering an alternative to this failed agenda. (Scottish Greens Scottish Parliament Manifesto, 2011, p. 1)

However, the emphasis on the global economic model as the causative factor in the ‘circumstances’ of environmental neglect is indicative of the Greens’ shift from being a single-issue party concentrating on environmental issues to one which embraces the full range of policy issues, presenting itself is an ideologically radical, left-wing alternative (Anderson 2016, Carter 2008, Wheatley et al. 2014). This positioning of the Greens is thus 
used to differentiate the party from others within their narrative of the political 'circumstances’ of, firstly, a UK-wide political context which has moved towards right-wing individualism on issues related to the economy and immigration, and, secondly, the growing centralisation of power in Scottish politics under the SNP:

Swapping a centralised UK Government for a centralised Scottish Government isn't the radical change that many wanted. Local community empowerment is an agenda Holyrood must embrace instead of seeing it as a threat. (Scottish Greens Scottish Parliament Manifesto, 2011, p. 24)

This attempt to differentiate the Greens from the other political parties is also evident in the analysis of the ideological 'values' of the party’s discourse, with the majority of the 'A Green Yes’ policy document outlining the party’s pro-immigration and pro-EU stance, and values such as political decentralisation, environmentalism, communitarianism, economic redistribution and the nationalisation of public services (Anderson 2016, Carter 2008, Wheatley et al. 2014). This exemplifies the central ideological cleavage between the Greens and the SNP within the pro-independence campaign.

Analysis of the emergent patterns in the Greens’ political discourse using the Fairclough and Fairclough (2012) framework also provides further evidence of the nuanced ideological and political positions of the party on the topic of the Games, as indicated in Figure 3: 


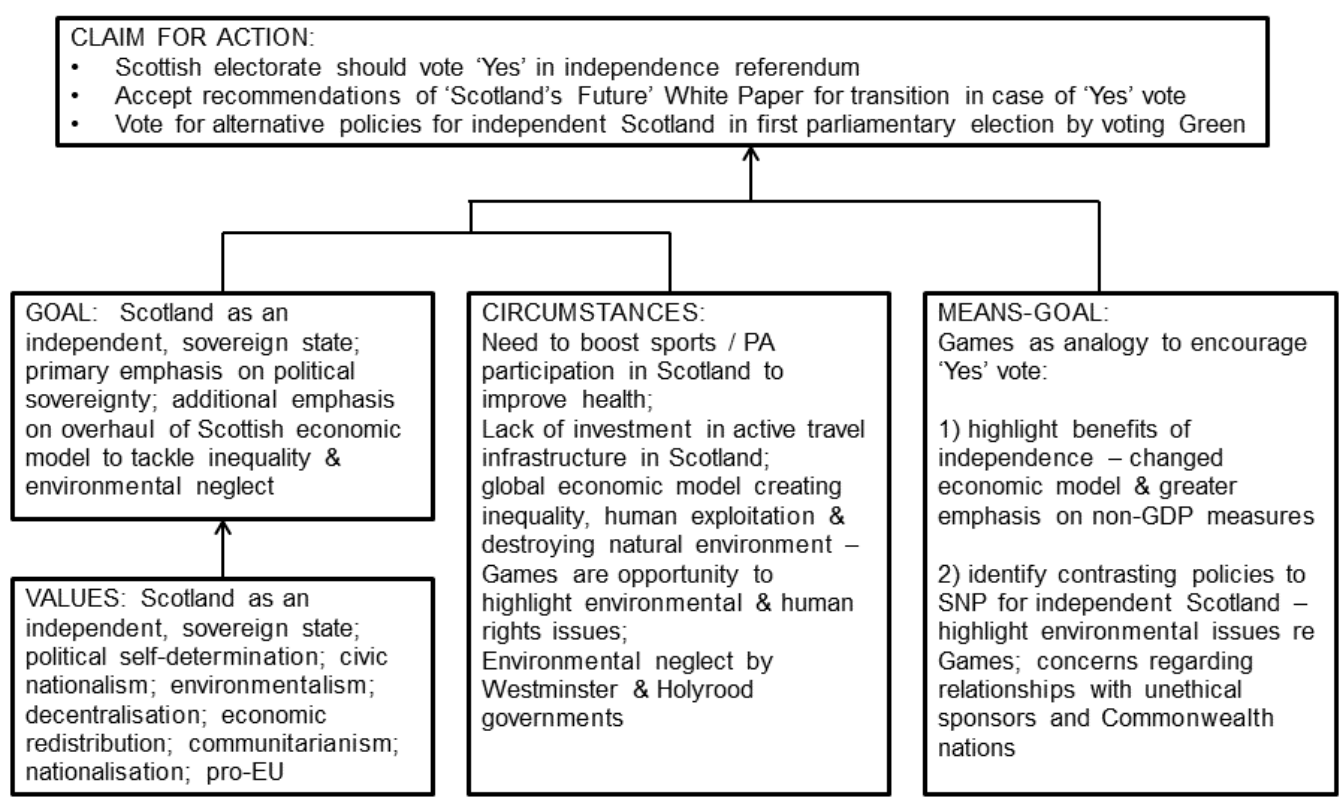

Figure 3 - Diagrammatic representation of Scottish Green Party political discourse regarding

\section{Commonwealth Games vis-a-vis Scotland's constitutional status}

Analysis of the Greens’ parliamentary contributions and press released referring to the benefits and/or legacy of the Games revealed that the vast majority of references related directly to sporting benefits. This overwhelming singular emphasis on the sporting benefits of the Games for Scotland was in contrast with discourse of other parties which highlighted both the sporting and economic legacies of the Games, thus placing greater emphasis on the event’s economic benefits as a form of 'economic boosterism’ (Horne 2007, Zimbalist 2015), whereas economic considerations were absent from the Greens' 'public narrative' of the Games:

The 2012 Olympics in London and the 2014 Commonwealth Games in Glasgow are major opportunities to transform attitudes to participation in sport. But they also pose a huge risk of presenting sport as being for elite athletes, with a consequent drain of money away from community facilities. Greens want to see 
active leisure for all - for all areas, ages and abilities. That is how we should measure success, not simply through gold medals. (Scottish Greens Local Elections Manifesto, 2012, p. 12)

This emphasis on increasing physical activity was also developed with specific reference to the use of the Games to encourage active travel, an unsurprising emphasis given the environmentalist ideology of the party. However, the Greens also emphasised using the Games to address inequality in sport, with particular reference made to gender inequality and LGBT human rights issues, thereby positioning the party as a champion of progressive political values with regard to the Games.

The Greens were apparently circumspect about the potential economic benefits of the Games, with no direct discussion of the economic impact of the Games in their discourse dataset. This appeared to reflect the party's stated preferences to move away from a neo-liberal economic model which viewed events such as the Games as a means to economic ends, emphasising instead the importance of viewing such events as ends in themselves in line with the party’s redistributive and communitarian ‘values’ (Carter 2008, Wheatley et al. 2014). Indeed, the only emergent pattern in the Greens' discourse regarding the economic benefits of the Games was restricted to a recurrent phrase that 'investing in sport is money well spent':

The challenge now, if we're to deliver a meaningful legacy, is to make sure the facilities and coaches are in place for this to become a reality, and that no one is priced out of a more active lifestyle. Investing in sport is money well spent. ('Glasgow 2014: an inspirational Games’, Scottish Greens press release, 2014) 
This phrase emphasised the party's belief that encouraging sports and physical activity has long-term health benefits, providing indirect economic benefits:

The challenge now, if we're to deliver a meaningful legacy, is to make sure the facilities and coaches are in place for this to become a reality, and that no one is priced out of a more active lifestyle. Investing in sport is money well spent. (‘Glasgow 2014: an inspirational Games’, Scottish Greens press release, 2014)

Indeed, the economic benefits, by way of Games-related tourism income, that were championed by other political parties were viewed with caution by the Greens given the potential environmental damage caused by the SNP-led Government's emphasis on boosting the number of international tourists visiting Scotland:

...my preference would be that we try and focus that on domestic tourism, that we try to focus it on visits from the rest of the UK, from other parts of Europe. And I believe if we're gonna have a sustainable, viable tourism industry, that's gonna have to be done with increasing surface travel rather than air travel for obvious peak oil and climate change reasons. (Patrick Harvie MSP, interview, prereferendum)

The Greens’ concerns about the lack of environmental consideration in the planning of the Games legacy was similarly emphasised in the party’s press release on the official opening of the M74 extension in June 2011: 
The new road is completely at odds with Scottish Government commitment and targets for cutting carbon emissions, and will make it more difficult for Glasgow to tackle its considerable air pollution problems in the run-up to the 2014 Commonwealth Games. ('Environmental movement: M74 opening “a dark day”’, Scottish Greens press release, 2011)

It appeared therefore that the Games were used as a form of leverage for highlighting specific policy concerns for the Greens, with the party opting for a mostly supportive stance regarding the Games overall whilst concentrating their Games-related political interventions on select areas of concern such as transport and community sports facilities.

The Scottish Conservatives - The 'Party of the Union' at the Games?

Attention now turns to analysis of the discourse of the Scottish Conservatives. Based on analysis of election manifestos from the pre-Games period and the party’s main policy document on the Scottish constitution, commonly referred to as the 'Strathclyde Commission', Figure 4 provides a diagrammatic representation of the Conservatives' political discourse relating to Scotland's constitutional status using the Fairclough and Fairclough (2012) framework, 


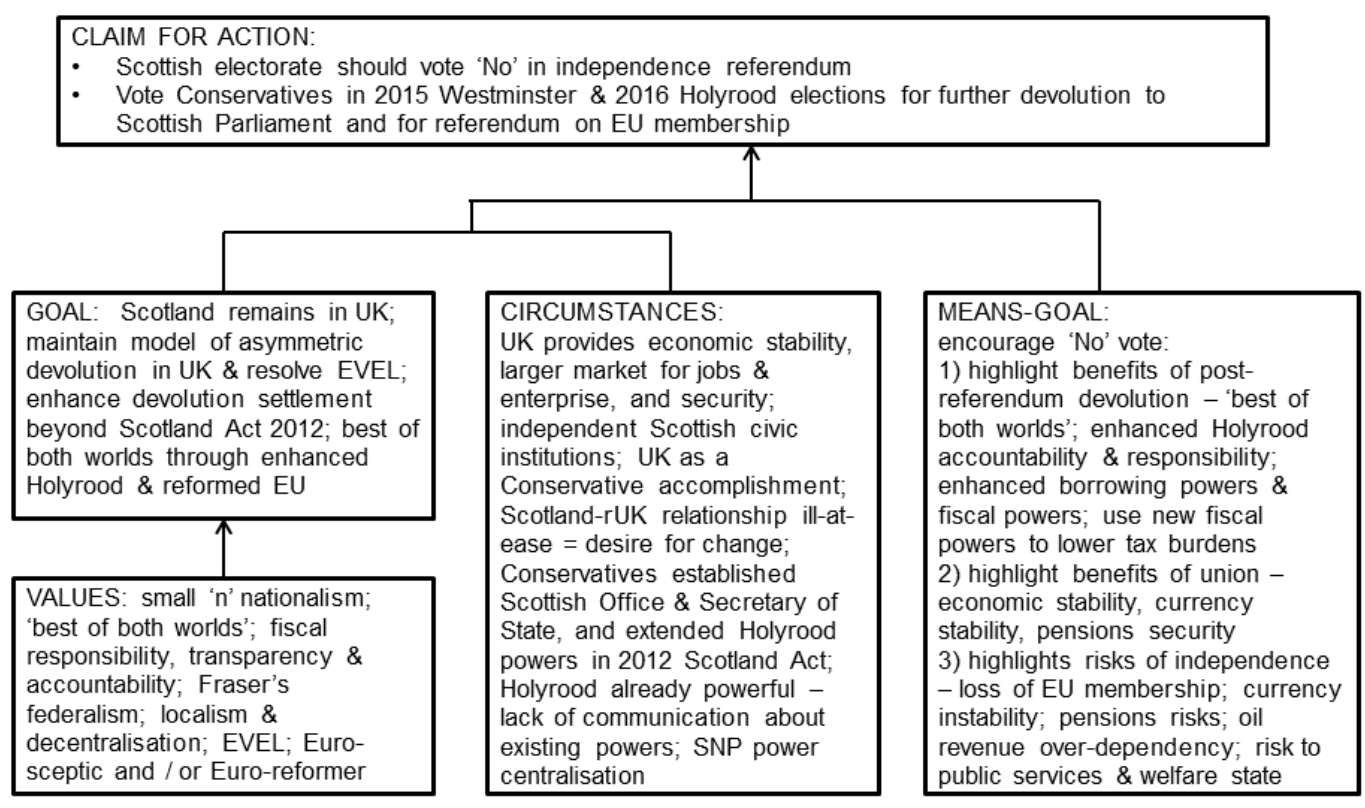

Figure 4 - Diagrammatic representation of Scottish Conservatives political discourse regarding Scotland's constitutional status

Given the strong degree of cooperation between the pro-union parties within the Better Together campaign, it is perhaps unsurprising that analysis of the Conservatives' 'public narrative' on the Scottish constitution contained numerous similarities with patterns found in the discourse of other pro-union parties, such as Labour and the Liberal Democrats. However, analysis of the Conservatives' discourse also illustrates that the pro-union parties retained nuanced positions on central issues within the constitutional debate.

Analysis of the Conservatives' discursive construction of Scotland's past and present ‘circumstances' begins to elicit some of these nuances. For example, on the topic of the union, the Conservatives clearly mirrored the strategy of Labour in terms of consistently highlighting its benefits for Scotland (Sharp et al. 2014, Wheatley et al. 2014). However, in contrast to Labour's portrayal of a 'sharing union' underpinned by the 'pooling and sharing 
of resources' and values of social justice and solidarity, the Conservatives' description of the union placed greater emphasis on economic and security considerations:

The two fundamental purposes of the Union are creating a large, single and fully integrated economic market for jobs and enterprise and assuring the common security of everyone within the state. (Strathclyde Commission 2014, p. 5; original emphasis)

The Conservatives' historic narration of the benefits of union for Scotland was also linked to the party's staunch pro-union constitutional stance:

The Conservative Party is and always has been the party of the Union. As Alan Trench has recently written for the IPPR, “The union is a Tory accomplishment”... The genius at the heart of the Anglo-Scottish Union of 1707 is that it allows both nations to blossom within a shared state. The Union was not and never has been an incorporating Union, requiring Scotland to assimilate as if she were nothing more than a northern region of England - or even an English colony. On the contrary, the Union is founded on the principle that Scottish institutions maintain their distinctive identity. (Strathclyde Commission 2014, p. 3; original emphasis)

This narrative of the 'circumstances' of the union demonstrates the Conservatives' position on the Scottish constitution in numerous ways. Firstly, the party's proclamation of the union as a 'Tory accomplishment' highlights a discursive contest with Labour for the status of the 'party of the union', with the Conservatives' reference to the historic foundations of the union 
being used to claim credit for these pre-suffrage developments. Secondly, the Conservatives' explicit refutation of arguments which contend that the union was 'incorporating' and resulted in the colonisation of Scotland by England demonstrates a willingness to directly challenge some of the foundational positions of Scottish nationalists on the union (Connell 2004, Dalle Mulle 2016, Sharp et al. 2014).

For the Conservatives, this use of referendum campaign discourse to promote the party's ideological 'values' was most clearly demonstrated through the publication of the Strathclyde Commission. The report explicitly links the party's stance on the Scottish constitution to principles of 'responsibility', 'transparency’ and 'accountability', using these principles repeatedly throughout:

Throughout our report, we have based our recommendations on strong Conservative principles of responsibility, transparency and accountability, which we believe are required for a sustained relationship of all four parts of the UK. (Strathclyde Commission 2014 p. 4; original emphasis)

These 'Conservative principles' are cited in support of the main recommendations of the Strathclyde Commission, such as the closure of the 'fiscal gap' in the Scottish Parliament by devolving additional fiscal powers to “create a more responsible Scottish politics” (Strathclyde Commission 2014, p. 8). This added responsibility is linked to the removal of the 'grievance culture' which blames Westminster for budgetary cuts (Leith and Soule 2011, Pittock 2008). The strategy of linking the Strathclyde Commission’s proposals to the Conservatives' ideological ‘values’ allowed the party’s referendum campaign discourse to serve a dual purpose, using the proposals to both counter the arguments of the pro- 
independence parties while also promoting the Conservatives’ policy positions. As part of this strategy, particular emphasis was placed on the opportunity to use new fiscal and borrowing powers to both boost economic growth and to lower the tax burden for the Scottish electorate.

Shifting attention to the Conservatives' Games-related discourse, a number of patterns are evident in the party's narratives regarding the Games represented in Figure 5 which demonstrates the Conservatives’ nuanced positions on the event:

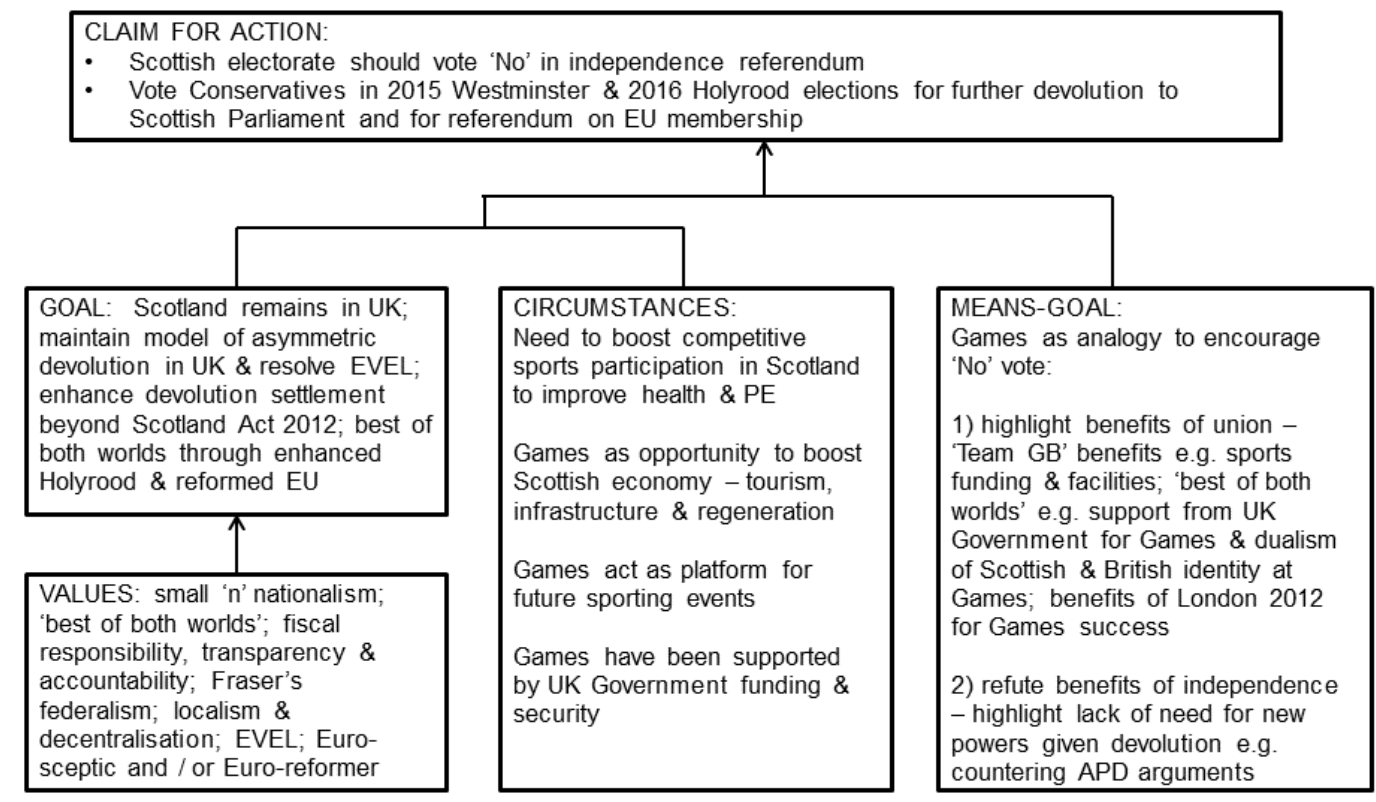

Figure 5 - Diagrammatic representation of Scottish Conservatives political discourse

regarding 2014 Commonwealth Games vis-a-vis Scotland's constitutional status

As was the case in the discourse of the other parties, the primary emphasis of the Conservatives' narratives of the Games focused upon the sporting benefits and legacy of the event. Within the 'sporting' category, the most frequently recurring theme related to the 
potential boost from the Games for sports and physical activity participation rates, with a particular emphasis on using Games-related facility development as a catalyst for this:

We will use the Games to encourage greater participation in sport across all age groups, and focus on leaving a lasting legacy of sporting facilities for after 2014. (Scottish Conservatives Scottish Parliament Elections Manifesto, 2010, p. 27)

Interestingly, however, the Conservatives placed a greater degree of emphasis than the other parties on the potential to use the Games to encourage health improvements in Scotland, despite the questionable evidence supporting such claims (Clark and Kearns 2015, McCartney et al. 2012, Mooney et al. 2015, Owe 2012, Stewart and Rayner 2016):

As someone with a health background, I naturally hope that the most important legacy that will come from Glasgow 2014 will be the improved physical health of our people_-and that must start with our young people. (Nanette Milne MSP, SP OR 11 June 2013, col. 20967)

Outside of the sporting domain, the Conservatives’ discourse contained a relatively low number of references to other aspects of the Games' benefits and legacy, such as economic, social and reputational impacts. This contrasted significantly with the discussion in the interviews, where more emphasis was placed on a range of non-sporting benefits and legacy aspects:

The Commonwealth Games are a prestige international event and they will bring substantial economic and social benefits to Glasgow and to Scotland especially in 
those non-Glasgow communities which will be hosting events. There will be some benefits to the UK in terms of visitors coming to Scotland but also wishing to spend time in other part of the UK, in terms of economic gains to the companies assisting with the construction of games venue, the production of retail products and the provision of additional employment. (Liz Smith MSP, survey, pre-referendum)

In contrast, the relationship between the Conservatives' discourse on the political aspects of the Games and the responses of the interviewees on this issue demonstrated a greater degree of alignment. Indeed, it can be argued that the party's discourse contained the highest degree of pro-union symbolism regarding the Games of all the unionist parties, with frequent references to 'Team GB' and the UK sports system, the positive impact of London 2012 as a UK-wide event (Ewen 2012, Jarvie 2017, MacRury and Poynter 2010), and support for the Games from the UK Government:

At the recent Commonwealth Games reception, which has been referred to several times, I was struck by how appreciative the Glasgow 2014 organisers were of the access, the support and the co-working with the London Organising Committee of the Olympic and Paralympic Games that has been on-going. (Ruth Davidson MSP, SP OR 8 November 2012, col. 13241-13242)

These frequent symbolic connections between the success of London 2012 and Glasgow 2014 were used to reiterate the benefits of the constitutional status quo for Scottish sport and society: 
Think of when Britain is called on to host these great events like the Olympics in 2012, or the Commonwealth Games this year. We do so as a United Kingdom, and we make them such special occasions for the whole world to see. (David Cameron MP, 'Prime Minister’s speech at Rally for the Union event', Scottish Conservatives press release, 2014)

This discursive strategy emphasised the devolved character of sport as a policy area while also illustrating the benefits of UK Government support for the Games, thus redolent of the 'best of both worlds' narrative which formed a central element of the pro-union discourse regarding the referendum. These narratives particularly emphasised the achievements of the UK as a nation at London 2012, the benefit of UK-wide support for Scottish sport, the unifying nature of London 2012 for the UK through a 'feel-good factor', and the support from the rest of the UK for Glasgow 2014 Games volunteers:

I’m voting 'No' as a patriotic Scot conscious of the practical case before us - a currency we all trust, Armed Forces we rely on, a pension when we retire, the knowledge we'll be cared for in hospital without the need to flash a credit card... And let's not take for granted the social and family ties that bond us together across the UK as well - symbolised in a small way for me by the fact that fully a quarter of the people who asked to volunteer in this summer's Glasgow Commonwealth games were from elsewhere in the UK. Simply put, the thing works. (Ruth Davidson MSP, 'Separating the country I love? No thanks’, Scottish Conservatives press release, 2014) 
These examples illustrate a pattern of allusion to the benefits of the union vis-à-vis the Games and the referendum, demonstrating that the Conservatives appreciated that events such as the Games could have both a unifying and divisive effect as regards Scottish and British identities, echoing the arguments of past academic analyses of the event (Harris and Skillen 2016, Haynes and Boyle 2008, Jarvie 2017, McDowell and Skillen 2015).

\section{Reflection on Methodological Synthesis}

As illustrated in the findings above, the methodological synthesis deployed in this project facilitated a more comprehensive analysis of the importance of consistent narratives in contemporary political discourse. However, despite the synergies outlined above, this synthesis of the frameworks of Somers (1994) and Fairclough and Fairclough (2012) creates certain theoretical contradictions and challenges. This is evident from Fairclough and Fairclough's aforementioned stance on the identification of narrative as a 'non-argumentative genre', as this contradicts the central premises of NA which emphasises the importance of narratives as both representations of and stimuli for human action in social contexts. Resolving this contradiction demands one of two approaches: either we dismiss the argumentative power of narrative forms entirely, in agreement with Fairclough and Fairclough (2012), or we refute their arguments on this particular issue. In the study described here, the latter approach was adopted. We contend that narrative forms are not a 'non-argumentative genre' as argued by Fairclough and Fairclough but instead represent a form of 'soft' argumentation for political action. Although our stance concurs with the Faircloughs' position on the primacy of 'imaginaries' of future circumstances as the argumentative basis for a given course of political action, we also contend that these future 'imaginaries' should be framed within a broader analysis of 'public narratives' of past and 
present circumstances. Such an approach allowed for a fuller contextualisation of the historical, social, economic and cultural developments which have influenced the political ideologies of each political party, thus facilitating an analysis of the constitutional developments which led to the 2014 independence referendum.

Furthermore, this refutation of Fairclough and Fairclough's position on the argumentative powers of narratives overcomes a problem regarding examples of political discourse which do not explicitly outline a future 'imaginary’ in relation to a given political issue. For example, instances of political speeches and publications which only contain descriptions of past or present circumstances (i.e. 'narratives') with no explicit suggestions or recommendations for future political action (i.e. 'imaginaries') are entirely plausible. Such instances require the analyst to speculate about the argumentative stance of a political actor given the lack of explicit argumentation or 'imaginary'. The alternative position adopted for this study with respect to the 'soft' argumentative qualities of narratives of past and/or present circumstances overcomes this problem. This contention regarding 'soft' argumentation suggests that political actors can represent circumstances in political discourse in a fashion which implicitly attempts to lead its audience to a particular course of action, without stating explicitly what this course of action is. For example, political discourse relating to the 2008 global financial crisis (as analysed by Fairclough and Fairclough) consists of potentially contrasting representations of the causes of the crisis, in narrative or other discursive forms, without necessarily containing an explicit argument for a particular course of action. It is therefore questionable whether representations of circumstances in narrative form can ever be entirely non-argumentative. It may instead be more appropriate to allow that such narratives can be implicitly argumentative than to dismiss their argumentative potential out of hand. Thus, although we accept Fairclough and Fairclough's (2012) position 
regarding the primacy of 'imaginaries' of future circumstances as the argumentative basis for a given course of political action, we argue that these future 'imaginaries' should be framed within a broader analysis of 'public narratives' of past and present circumstances.

A methodological synthesis of the sort described above has the potential to foster original contributions to the academic study of the relationship between politics, nationalism and sport. The application of the conceptual frameworks of Somers (1994) and Fairclough and Fairclough (2012) have demonstrated the potential benefits of the 'methodological bricolage' advocated by Denzin and Lincoln (2003), with the complementarity of the two frameworks located in a shared emphasis on the roles of narrative in contemporary political discourse. The synthesis of these frameworks facilitated the exploration of the character of the 'public narratives' of each party on the Scottish constitution and the 2014 Games, while simultaneously providing an opportunity to present the findings of the data analysis through the heuristic application of Fairclough and Fairclough's (2012) framework. Although the application of these complementary theoretical frameworks was specifically focused on the 2014 Games as a relatively isolated event, we argue that the same (or a similar) methodological approach could be replicated to study a range of contrasting events or developments, whether in sporting or wider domains worthy of political consideration. It is hoped, therefore, that the original methodology employed in this particular study can be used to inspire or influence other academics to conduct academic research using similar methodological approaches in a variety of contrasting contexts.

\section{Conclusion}


The findings derived from this methodological synthesis have the potential to make an original contribution to furthering academic understanding of the relationship between sport and politics in a number of ways. Firstly, the direct engagement with politicians via the interviews and surveys facilitated critical evaluation of the claims of past academic literature on the politics of international sporting events. In this respect, it has been possible to illustrate that many of the widely held beliefs about these events, such as those linked to the 'myth of autonomy’ (Allison 1993) and the ‘boosterism’ logic of hosting benefits (Horne 2007, Horne and Manzenreiter 2006, Zimbalist 2015), were also manifest in the discourse and narratives espoused by political actors in the Scottish context. Future academic research which examines the politics of international sporting events (and sporting issues, more broadly) should therefore continue to engage with politicians directly, given that this provides an opportunity to gain a fuller understanding of the reasons behind their political perspectives on sport. Furthermore, such interaction also facilitates an opportunity to directly question and/or challenge some of the unexamined assumptions about the politics of sport that are frequently perpetuated by political actors, thereby offering the possibility of encouraging further reflection by these actors on their personal ideological positions and inconsistencies.

Given that the findings of the study have provided analytical insights into both the nature of political discourse in relation to two significant events, and also into the strategic thinking of the political actors involved in creating this discourse, it is hoped that future studies of the relationship between sport and politics can further develop this understanding of such phenomena. This original methodological approach can be replicated to explore the political discourses of future sporting events such as the Commonwealth Games or other sporting 'mega-events'. Furthermore, future research studies on the interconnection between sport and politics in the Scottish and British contexts will undoubtedly be of considerable academic 
interest, in light of the significant constitutional debates which are likely to continue over the coming years as the UK leaves the EU.

As a broad policy area, sport will remain a political consideration as the implications of future governmental decisions shape the funding landscape at international, national and local levels. As a consequence, the persistence in contemporary political discourse of the 'myth of autonomy' (Allison, 1993) that 'sport and politics should not mix' highlights the necessity of further academic examination of such spurious claims. Although it can be argued that academics operating in the fields of the politics and sociology of sport have a vested interest in challenging such myths as part of an ongoing project to raise the status of sport in both political and academic circles, it is nevertheless important to critique the impact of commonly held beliefs about the benefits of investing vast sums of public money in hosting sporting events such as the Commonwealth Games, or indeed investing in sport more generally. Even though this would not necessarily require a direct methodological replication of the processes followed in this study, the fundamental methodological principles which underline the importance of critically examining political discourse have numerous applications within the political and sociological study of sport. We argue, therefore, that challenges to prevailing political perceptions of sport will allow for a more diverse array of methodological, theoretical and ideological approaches, thus addressing the limitations of the ideological lacuna which arguably prevails in contemporary political thought and discourse on sport. 


\section{References}

Allison, L., 1993. The changing context of sporting life. In: L. Allison, ed. The changing politics of sport. Manchester: Manchester University Press, 1-14.

Anderson, P., 2016. The 2016 Scottish Parliament election: a nationalist minority, a Conservative comeback and a Labour collapse. Regional \& federal studies, published online ahead of print, DOI: 10.1080/13597566.2016.1193488.

Arnott, M., and Ozga, J., 2010. Nationalism, governance and policymaking in Scotland: The Scottish National Party (SNP) in power. Public money \& management, 30 (2), 91-96.

Bakhtin, M., 1981. The dialogic imagination: four essays (trans. and ed. C. Emerson and M. Holquist). Austin, TX: University of Texas Press.

Berling, T.V. and Beuger, C., 2013. Practical reflexivity and political science: strategies for relating scholarship and political practice, Political science \& politics, 46 (1), 115-119.

Blommaert, J., 2005. Discourse. Cambridge: Cambridge University Press.

Bourdieu, P., 1990. In other words: essays towards a reflexive sociology. Cambridge: Polity Press.

Bruner, J., 1990. Acts of meaning. Cambridge, MA: Harvard University Press. 
Carter, N., 2008. The Green Party: emerging from the political wilderness? British politics, 3, 223-240.

Charteris-Black, J., 2014. Analysing political speeches: rhetoric, discourse and metaphor. Basingstoke: Palgrave Macmillan.

Clark, J., and Kearns, A., 2015. Pathways to a physical activity legacy: assessing the regeneration potential of multi-sport events using a prospective approach. Local economy, 30 (8), 888-909.

Connell, L., 2004. Scottish nationalism and the colonial vision of Scotland. Interventions, 6 (2), 252-263.

Crossley, M., 2000. Introducing narrative psychology. Buckingham, UK: Open University Press.

Czarniaska, B., 2004. Narratives in social science research. London: Sage.

Daiute, C., and Lightfoot, C., 2004. Editors’ introduction: Theory and craft of narrative analysis. In: C. Daiute and C. Lightfoot, eds. Narrative analysis: Studying the development of individuals in society. London: Sage, 7-18.

Dalle Mulle, E., 2016. New trends in justifications for national self-determination: evidence from Scotland and Flanders. Ethnopolitics, 15(2), 211-229. 
Denzin, N.K., and Lincoln, Y.S., 2003. Introduction: the discipline and practice of qualitative research. In: N.K. Denzin and Y.S. Lincoln, eds. Strategies of qualitative inquiry (2nd ed.). London: Sage, 1-45.

Ewen, N., 2012. Team GB, or no Team GB, that is the question: Olympic football and the post-war crisis of Britishness. Sport in history. 32 (2), 302-324.

Ezzy, D., 1998. Theorising narrative identity: symbolic interactionism and hermeneutics. Sociological quarterly, 39(2), 239-252.

Fairclough, I. and Fairclough, N., 2012. Political discourse analysis: a method for advanced students. London: Routledge.

Fairclough, N., 1992. Discourse and text: linguistic and intertextual analysis within discourse analysis. Discourse and Society, 3, 193-217.

Fairclough, N., 2003. Analysing discourse: textual analysis for social research. London: Routledge.

Fairclough, N., 2015. Language and power ( $3^{\text {rd }}$ ed.). London: Routledge.

Fairclough, N., and Wodak, R., 1997. Critical discourse analysis. In: T. van Dijk, ed. Introduction to discourse studies. London: Sage, 258-284. 
Frank, A., 2005. What is dialogical research, and why should we do it? Qualitative health research, 15, 964-74.

Gergen, K., 1999. An invitation to social construction. London: Sage.

Gergen, K., 2001. Social construction in context. London: Sage.

Jones, I., 2015. Research methods for sports studies ( $3^{\text {rd }}$ ed.). London: Routledge.

Guba, E.G., and Lincoln, Y.S., 2005. Paradigmatic controversies, contradictions and emerging confluences. In: N.K. Denzin, and Y.S. Lincoln, eds. The Sage handbook of qualitative research (3rd ed.). London: Sage 191-216.

Gubrium, J., and Holstein, J., 1998. Narrative practice and the coherence of personal stories. Sociological quarterly, 39(1), 163-87

Harris, J., and Skillen, F., 2016. Sport, gender and national identities. In: N. Blain, D. Hutchison, and G. Hassan, eds. Scotland's referendum and the media: national and international perspectives. Edinburgh: Edinburgh University Press, 83-96.

Haynes, R., and Boyle, R., 2008. Media sport. In: N. Blain and D. Hutchinson, eds. The media in Scotland. Edinburgh: Edinburgh University Press, 253-270.

Hearn, J., 2002. Narrative, agency, and mood: on the social construction of national history in Scotland. Comparative studies in society and history, 44 (4), 745-769. 
Hermans, H., 2001. The dialogical self: toward a theory of personal and cultural positioning. Culture and psychology, 7(3), 243-81.

Horne, J., 2007. The four 'knowns' of sports mega-events. Leisure studies, 26 (1), 81-96.

Horne, J., and Manzenreiter, W., 2006. An introduction to the sociology of sports megaevents. The sociological review, 54, 1-24.

Jarvie, G., 2017. Sport, the 2014 Commonwealth Games and the Scottish referendum. In: A. Bairner, J. Kelly, and J.W. Lee, eds. The Routledge handbook of sport and politics. London: Routledge, 209-221.

Jedlicka, S., 2014. The normative discourse of anti-doping policy. International journal of sport policy and politics, 6 (3), 429-442.

Kelly, J., 2011. 'Sectarianism’ and Scottish football: Critical reflections on dominant discourse and press commentary. International review for the sociology of sport, 46 (4), 418435.

Lee, J., 2015. The meaning of sport: sociolinguistic analysis of sport and energy drink brands’ advertising messages. International journal of sport communication, 8 (2), 174-192.

Leith, M.S., and Soule, D.P.J., 2011. Political discourse and national identity in Scotland. Edinburgh: Edinburgh University Press 
Liao, J., and Markula, P., 2009. Reading media texts in women’s sport: critical discourse analysis and Foucauldian discourse analysis. In: P. Markula, ed. Olympic women and the media: international perspectives. Basingstoke: Palgrave Macmillan, 30-49.

MacRury, I., and Poynter, G., 2010. 'Team GB' and London 2012: the paradox of national and global identities. The international journal of the history of sport, 27 (16-18), 2958-2975.

McAdams, D., 1993. The stories we live by: personal myths and the making of the self. New York: Morrow.

McCartney, G., Hanlon, P., and Bond, L., 2012. How will the 2014 Commonwealth Games impact on Glasgow’s health, and how will we know? Evaluation, 19 (1), 24-39.

McDowell, M., and Skillen, F., 2015. The 1986 Commonwealth Games: Scotland, South Africa, sporting boycotts, and the former British Empire. Sport in society, 20 (3), 384-397.

McNair, B., 2011. An introduction to political communication (5th ed.). London: Routledge.

Mean, L., and Kassing, J., 2008. Identities at youth sporting events: a critical discourse analysis. International journal of sport communication, 1 (1), 42-66.

Mooney, G., McCall, V., and Paton, K., 2015. Exploring the use of large sporting events in the post-crash, post-welfare city: a ‘legacy’ of increasing insecurity? Local economy, 30 (8), 910-924. 
Owe, E., 2012. Legacy lessons from past large-scale sporting events: review of evidence. Edinburgh: Scottish Government. Available from: http://www.gov.scot/Publications/2012/10/7250. Last accessed on 8/8/2017.

Piggin, J., 2014. Discourse analysis and its application to sport policy analysis. In: I. Henry and L. Ko, eds. Routledge handbook of sport policy. London: Routledge, 23-32.

Piggin, J., Jackson, S., and Lewis, M., 2009. Telling the truth in public policy: an analysis of New Zealand sport policy discourse. Sociology of Sport Journal, 26 (3), 462-482.

Pittock, M., 2008. The road to independence? Scotland since the sixties. London: Reaktion.

Ricoeur, P., 1984. Narrative and time (vol. 1). Chicago, IL: University of Chicago Press.

Rich, K.A. and Giles, A.R., 2015. Examining whiteness and Eurocanadian discourses in the Canadian Red Cross’ swim program. Journal of sport and social issues, 38 (5), 465-485.

Riessman, C. K., 1993. Narrative analysis. London: Sage.

Sharp, J., Cumbers, A., Painter, J., and Wood, N., 2014. Deciding whose future? Challenges and opportunities of the Scottish independence referendum 2014 for Scotland and beyond. Political geography, 41, 32-42. 
Silk, M.L., Andrews, D.L., and Mason, D.S., 2005. Encountering the field: sports studies and qualitative research. In: D.L. Andrews, D.S. Mason and M.L. Silk, eds. Qualitative methods in sports studies. New York, NY: Berg, 1-20.

Smith, B. and Sparkes, A., 2008. Contrasting perspectives on narrating selves and identities: an invitation to dialogue. Qualitative research, 8(1), 5-35.

Somers, M., 1994. The narrative constitution of identity: a relational and network approach, Theory and society, 23, 605-649.

Sparkes, A.C., 2002. Telling tales in sport and physical activity: a qualitative journey. Champaign, IL; Human Kinetics.

Sparkes, A.C. and Smith, B., 2014. Qualitative research methods in sport, exercise and health: from process to product. London: Routledge.

Stewart, A., and Rayner, S., 2016. Planning mega-event legacies: uncomfortable knowledge for host cities. Planning perspectives, 31 (2), 157-179.

Titscher, S., Meyer, M., Wodak, R., and Vetter, E., 2000. Methods of text and discourse analysis. London: Sage.

van Dijk, T., 1996. Discourse, power and access. In: C. Caldas-Coulthard and M. Coulthard, eds. Texts and practices: readings in critical discourse analysis. London: Routledge, 84-104. 
Wacquant, L. J. D., 1992. The structure and logic of Bourdieu’s sociology. In: P. Bourdieu and L.J.D Wacquant. An invitation to reflexive sociology (eds.). Cambridge: Polity Press, 259.

Wheatley, J., Carman, C., Mendez, F., and Mitchell, J., 2014. The dimensionality of the Scottish political space: results from an experiment on the 2011 Holyrood elections. Party politics, 20 (6), 864-878.

Whigham, S., 2017. The SNP, Scottish Labour and Glasgow 2014 - contrasting political narratives of the 2014 Commonwealth Games. Scottish affairs, 26 (3), 271-296.

Wolter, S., 2015. A critical discourse analysis of espnW: divergent dialogues and postfeminist conceptions of female fans and female athletes. International journal of sport communication, 8 (3), 345-370.

Zimbalist, A., 2015. Circus maximus: the economic gamble behind hosting the Olympics and the World Cup. Washington, D.C.: Brookings Institution Press. 